\title{
TTR
}

Traduction, terminologie, re?daction

\section{Theo Hermans. Translation in Systems. Descriptive and System-oriented Approaches Explained. Manchester, St. Jerome Publishing, 1999.}

\section{Candace Séguinot}

Volume 13, numéro 1, 1er semestre 2000

Idéologie et traduction

Ideology and Translation

URI : https://id.erudit.org/iderudit/037401ar

DOI : https://doi.org/10.7202/037401ar

Aller au sommaire du numéro

Éditeur(s)

Association canadienne de traductologie

ISSN

0835-8443 (imprimé)

1708-2188 (numérique)

Découvrir la revue

Citer ce compte rendu

Séguinot, C. (2000). Compte rendu de [Theo Hermans. Translation in Systems. Descriptive and System-oriented Approaches Explained. Manchester, St. Jerome Publishing, 1999.] TTR, 13(1), 198-202. https://doi.org/10.7202/037401ar d'utilisation que vous pouvez consulter en ligne.

https://apropos.erudit.org/fr/usagers/politique-dutilisation/ 
Theo Hermans. Translation in Systems. Descriptive and Systemoriented Approaches Explained. Manchester, St. Jerome Publishing, 1999.

If there is a prize for the most literate of English-language writers on 
translation, there has never been any doubt in my mind that Theo Hermans would be a strong contender. This book supports that view: from the tightly woven Preamble on the translation of Thomas Mann to the choice of the word 'scienticity' to describe Gideon Toury's work on empirical laws, his language is a delight.

The series in which this book is published, Translation Theories Explained, dedicates each volume to the development, essential ideas, and possible future directions of one approach to translation theory. The idea was to make theories available in a form that would be useful to students as well as scholars, and to this end there is a glossary of terms with the senses used in this volume. Though I doubt the editor's statement that this book would be useful to students dealing with translation theory for the first time, I am going to rush to recommend this book to graduate students and to anyone seriously interested in translation theory or literary translation.

Having praised his gift for writing, it's also true, as Hermans himself admits in the preface, that the title of this book is a little misleading. To understand the sense in which the terms "descriptive" and "system" on the cover are used is to understand the contents of the book. In brief, this is an explanation of three areas of recent work in translation. The first, descriptive or empirical studies, has the least obvious interpretation. Neither term refers to the focus on methodology associated with behavioural science. "Description", Hermans suggests, is best understood for the work in question in opposition to prescription (p. 35). This is the orientation associated with the work of Gideon Toury. The "system" of the title comes from the second area of research, polysystem theory. The third area deals with cultural practice, also referred to here as the Manipulation school. As Hermans says (p. 102), each of these areas of research could have existed independently; the connection between them is "...a matter of historical accident and conceptual convenience."

The variety of labels for this particular school reflects the sociological reality of the ties that Hermans is explaining. This approach viewed from the outside - and I say that because Hermans himself is a central figure in polysystem theory - may seem less of a collective than an association of groups of researchers as well as individuals known more for specific contributions than for shared influences and ideas. What Hermans excels at is tracing those ties, crediting individuals for their 
specific contributions, and pointing out what he sees as problems. An example? Here he is describing Even-Zohar's contribution (p. 110): "The boldness of the abstract thought here has as its flip-side an eagerness to rush into generalizations."

The introduction contextualizes the movement not only historically but as an example of a paradigm shift. One of the interests of this book is the documenting of the pivotal role of a critical mass, not of scholarship in the sense of publications, but of individuals who have come to agreement on certain issues. As the second chapter explains, an early (1953) essay by John McFarlane found no echo as a solitary effort although it already contained the ideas associated with the "disciplinary matrix" that would arise after the meeting of some of the Czech and Slovak scholars with James Holmes. That ongoing connection may have accounted for the emphasis on stylistics in the work of this group and for the adoption of key notions like translation-as-communication.

The individuals who came to consensus on these ideas met over the course of three conferences (Leuven 1976, Tel Aviv 1978, and Antwerp 1980). This common ground is explained in Chapter 3 through an expanded reading of a passage from Hermans' "programmatic introduction" to The Manipulation of Literature. There was to be a focus on literature as a dynamic system, there was a need for there to be an interplay between theoretical models and case studies, the approach to translation was to be descriptive (in their very specific sense), targetoriented, functional and systemic. There was an interest in norms and constraints, in the relation between translation and other forms of text processing, in the place of translation within a given literature and the interaction between literatures.

How the next chapter on Undefining Translation fits in becomes clearer on the second reading. It is centered on the question of identifying what is a translation, and what is something else. The link to the theoretical shift, and the explanation for the role of description, is that translation is not to be understood through definition but, in Gideon Toury's words (p. 49), "...whether it [a text] is regarded as a translation..." Another result of the shift was the re-interpretation of the meaning of the term "equivalence". The traditional notion was that equivalence was a goal to be achieved; for Toury "equivalence" became a cover term for the relationship between source and target texts. In a later chapter (Beyond 
norms) discussing translation and ideology, Hermans questions the legitimacy of this relational definition given the fact that post-colonial studies have demonstrated the basic inequality of language relationships.

Hermans then discusses the merits of a variety of what he calls descriptive models of translation that correspond to a systematic approach, ranging from Nida to Toury, Van Leuven-Zwart to Stegeman and Lambert and Van Gorp. This is followed by a chapter on norms with a review of models of norm-governed translational behaviour starting with Levy's decision process and then on to Toury, Chesterman, and Nord before an excellent discussion of norm theory with some comments on productive grounds for the study of norms in translation. Beyond norms, as the next chapter is called, looks at the notion of translational laws Toury's work, of which Hermans is skeptical, - and Chesterman's contribution. He then looks at a second way to go beyond norms, which is to look at the values inherent in them. This leads into the exploration of the history of thinking about translation starting with the work of Lieven D'hulst. How does one assign periods to theory when theory and practice are not necessarily aligned? Should historiography start with a term and trace its changing meaning, or start with a concept and trace the means of expression?

Chapter Eight begins with the Russian formalist and Prague structuralist origins of polysystem theory, then explores the terms of the theory ( Hermans suggests that the "poly" in "polysystem" is redundant and announces that he will drop it, which explains the "systems" in the title) and the kinds of analysis that have been carried out by Yahalom and D'hulst. He suggests, though the reader might question the linearity, that there have been four lines of development to overcome the limitations of polysystem theory. The first is the work of José Lambert on mass media, the second André Lefevere's work on ideology and poetics, and the third the influence of Pierre Bourdieu (in spite of his being anti-systems) on Lefevere, Jean-Marc Gouanvic and Daniel Simeoni through his concepts of field and habitus.

As the fourth line of development is the centre of some of the author's own interests, the work of system-theorist Niklas Luhmann has a chapter of its own. Hermans suggests that looking at translation from this systems perspective might be a way of understanding the internal organization and evolution of translation. Luhmann's use of the concept 
"communication ", for example, has to do with the construction rather than the transmittal of meaning. Meaning is construed by the recipient as the result of the recognition of selectivity. The notion of selectivity, the temporalized nature of semantics, the role of expectation in cementing social structures together, all these are consistent with a description of translation as a norm-governed behaviour.

Hermans uses Luhmann's distinction between first and secondorder observation to criticize translation criticism and even more directly empirical research. As there can be no objectivity in observation, he concludes that self-reflexive translation research must be based on theory, analysis, and history. This view is echoed in the final chapter where Hermans comments on where he thinks the descriptive and systemic paradigm is likely to go. Both here and in the chapter just before it where he addresses the criticisms that have been raised about this approach, he points out the need to move beyond the structurally-inspired model, and admits that the original identity of the paradigm is unravelling. He also astutely notes that innovations are coming from what he terms committed approaches. In the final analysis, this is a text that is as philosophically lucid as it is honest.

Candace Séguinot York University 